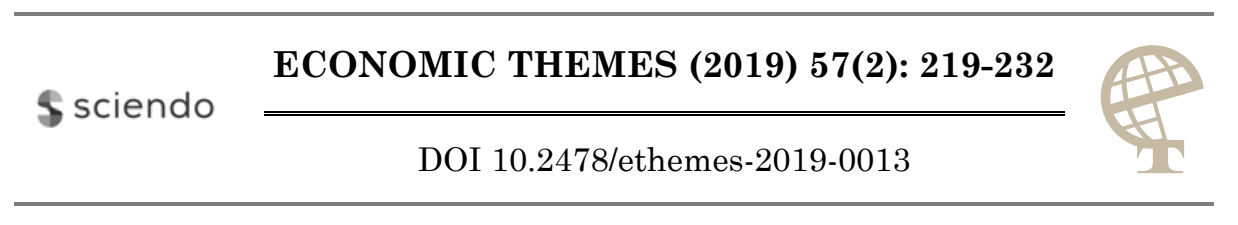

\title{
PERSPECTIVES OF DEVELOPMENT OF RURAL TOURISM OF THE REPUBLIC OF SERBIA
}

\section{Dejan Ž. Đorđević}

University of Niš, Faculty of Economics, Republic of Serbia

$\bowtie 565$ geo@gmail.com

\section{Vukašin Šušić}

University of Niš, Faculty of Economics, Republic of Serbia

$\bowtie$ vukasin.susic@eknfak.ni.ac.rs

\section{Ivana Janjićc}

Innovation Center, University of Niš, Republic of Serbia

UDC

338.48-44

$(1-22)$

(497.11)

Review paper

Received: 20.03.2019

Accepted: 30.05.2019

\begin{abstract}
Rural tourism represents the tourism in rural households, as well as holidays and stays in rural areas, events, festivals, recreations, productions and sales of handicrafts, crafts and agricultural products. Rural tourism is especially suitable for the revitalisation of degraded rural areas, ensuring their sustainability in the future, through creating new work places, increasing the diversity of occupations, rural crafts, and also preserving the landscape and nature. The development of rural tourism of the Republic of Serbia could play an important role in the country's rural development and economic development in general. Thanks to its diverse relief and preserved nature, Serbia has significant resources in rural tourism at its disposal, but the number of negative factors that prevent more intensive growth of this economic branch is not negligible at all. One of the most important problems, but not unsolvable one, is the extinction of rural settlements in Serbia.
\end{abstract}

Keywords: rural tourism, village, sustainable tourism, rural area

JEL classification: L84, Q18, O11

\section{Introduction}

The influence of global processes on economic development is reflected in the intensity and direction of tourism flows, as well as in the development of specific 
types of tourism, where rural tourism appears as a significant and growing segment. Modern people yearn for emotional stimulus, where they want to personalise the experience of non-material qualities, seeking the ambience, aesthetics, atmosphere and peace. These new trends in the tourism market have influenced the emergence of tourism of special interests, that is, the emergence of rural tourism. The demand for this form of tourism is steadily increasing as tourists are more and more interested in interacting with nature, getting to know new areas, people, other cultures and customs. Rural tourism is a multiple activity that includes holiday in the countryside, but also special forms of nature tourism, ecotourism, hiking, mountaineering, riding, adventurous tourism, sport and health tourism, hunting and fishing etc.

As an organised activity, the development of rural tourism in the Republic of Serbia started a little more than a quarter of a century ago (at the end of the 1970s ) Hopfully, it could represent an important factor of rural development. The preserved nature, clean air, favourable climate, rich flora and fauna, hydrographic potential and a large number of cultural and historical monuments, ethnographic elements, represent the potential of the Republic of Serbia for the development of high quality, appriciated rural tourism.Rural settlements are areas that abound with preserved natural and cultural resources necessary for the development of tourism, but significantly lag behind in the economic development in relation to urban areas. The development of rural areas itself faces a number of limiting factors, such as scarce knowledge of new approaches to the development of rural economy, lack of legislation to ensure the coordinating role of the state in the integral development of rural tourism, underdeveloped infrastructure in rural settlements, and the like.

The starting points of this research are as follows:

- Serbia has comparative advantages for the development of rural tourism, which development depends on the achieved level of the development of rural areas

- despite the rich resource base, the rural tourism in the Republic of Serbia is still in the initial stage of development

- greater investments in the development of rural tourism by exploiting the potential and eliminating the restrictions on rural areas should affect the employment of the local population with the achievement of economic profit, reduction of regional disparities and greater motivation for young people to stay in rural areas.

\section{Theoretical concept of rural tourism}

According to the OECD definition, rural settlements are areas characterised by a small number of inhabitants, with the dominant use of land and forests for the life of the population, appropriate social structure, customs and rural identity (OECD, 1994). The rural area could be defined as an environment with a low concentration 
of population, focusing on agriculture, and characterised by special customs and rural identity.Rural areas are typically the following: the areas with the settlements (houses, auxiliary and other facilities) and the infrastructure of the villages that occupy a smaller part of the area and dominated by fields, ponds, forests, aquatic areas, mountains, areas rich in arable agricultural land, areas where most people spend their work hours on the field, areas at a greater distance from urban areas and with inadequate infrastructure (Ashley, Maxwell, 2001).

Tourism in rural areas does not represent today's phenomenon, it emerged from the period of the industrial revolution that represents the beginning of intensification of the development of rural tourism. The preserved nature of rural areas with rich anthropogenic heritage has particularly contributed to a special appeal they give to people from highly urbanised cities. Rural tourism is imposed as an alternative opportunity and a solid basis for the adequate development of rural areas and as an element of better exploitation of the comparative advantages of rural areas. Rural tourism is not only considered a type of tourism, but also a kind of instrument for the development of rural areas, their revitalisation and increasing attractiveness. (Hakkarainen, Seija, 2008).

Rural tourism represents the tourist valorisation of agrarian areas, natural resources, cultural heritage, rural settlements, local traditional customs and products. Specially designed touristic products reflect the identity of the area and meet the needs of guests in terms of accommodation, food and beverage services, recreation and activities, animation and other services, with the aim of sustainable local development, but also by providing adequate responses to the needs of a potential tourist. Rural tourism actually implies and includes a range of activities, services and other contents organised by the local population in family households in order to attract tourists and create added value to the touristic product (Rural Tourism Development Strategy of the Split-Dalmatia County, 2009).

Since rural tourism is based on natural resources, rural heritage, rural lifestyle and activities in rural areas, the key elements of rural tourism are as follows (Hall, Roberts, Mitchell, 2003):

1. it is located in rural areas;

2. it is based on small entrepreneurship, open area, direct contact with nature, cultural heritage and natural values;

3. settlements and buildings are smaller in size than in urban tourism;

4. it is traditional in character, develops slower, closely related to the local population, developed by the local community, has long-term benefits for the rural area, a high percentage of income is used in the rural community;

5. it represents a complex pattern of rural environment, economy, history and location. 
Rural tourism, as an economic and social activity, is an integral part of sustainable tourism, and therefore, the sustainable development of rural tourism represents the respect of general principles of sustainable development and ethical changes among all participants in the tourism process. The notion of sustainability is in a strong interaction with rural tourism and is crucial and essential for the development of rural tourism. An important prerequisite for the further development of tourism is the preserved and healthy environment, which makes rural environments the basic potential for sustainable tourism development (Lane, 1994). Sustainable development of rural tourism is based on an integrated approach that emphasises the preservation of the environment, cherishing cultural content of the local population, optimal satisfaction of tourist needs, realization of economic profit etc. (Jovičić, 2002). The main goal of the sustainable development policy is to transform the image of thetraditional village from the place where people only deal with agriculture and where the poor quality of services abides, into the economically strong area that offers a quality product.

The emergence of new trends urges the demand for special forms of rural tourism, which is based on the desire of a modern man to return to nature and tradition and includes certain vacations in nature, trips to rural areas, visits to some events, festivals and the like. Nowadays, it is possible to distinguish several special forms of rural tourism, which correspond to rural tourism. Thus, ecotourism implies the activities that support the preservation and improvement of the quality of life resources, where ecologically conscious tourists try to reduce their negative effects on the environment by their own actions. Agrotourism represents a symbiotic relationship between tourism and agriculture. It is a key element for ecological and socially responsible tourism in rural areas. Agrotourism involves several special forms of tourism: farm holidays, village holiday homes, camping on farms, stays in centres for equestrian sports etc. Agroecotourism is a combination of ecotourism and agrotourism (Scialabba, Williamson, 2004).

Of course, forms of tourism that do not belong to rural tourism, but are closely related to it, should be also mentioned here, especially when they take place in rural areas. Cultural tourism may represent a trip to rural areas in order to visit monuments of culture, museums, galleries and cultural events. In gastronomic tourism, the production of food specialties in traditional way is a cause for organising events in rural areas. Wine tourism is also associated with gastronomic and rural tourism and represents a product that has evolved from rural tourism (Hall et al., 2002). Sports and recreational tourism reflect the need of tourists to spend their time in nature, adventure tourism is basically oriented towards recreation, while camping tourism implies accommodation and stay of tourists in camps that are most often located within agritourism farms. Hunting and fishing tourism is typical for rural areas, weither it be forest, agricultural or aquatic land in question. Residential tourism refers to the occasional stay of the urban population in their own facilities in rural areas during the weekend, holiday or vacation. 


\section{The degree of development of rural tourism of the Republic of Serbia}

Rural areas of the Republic of Serbia occupy almost three-quarters of the national territory, and according to the OECD data, rural areas in Serbia cover $85 \%$ of the country's territory, with more than a half of the total population. Important components of these areas are natural resources (agricultural land, forests, water, flora and fauna), cultural and historical heritage etc. (Ministarstvo ŽSPP, 2009).

The main problems in the rural regions of Serbia are the isolation and the distance of rural settlements from urban centres. Lack of adequate infrastructure makes communication difficult, reduces available opportunities and creates serious problems, especially for women and younger population. The long-term neglect of rural areas and agriculture in the rural development policy and strategy has resulted in migration of the population and change in socio-demographic structure in rural areas. Long-term migration of the population on the village-town relation, accompanied by insufficiently adequate social and rural policies, has led to the aging of the population in rural areas, and consequently to depopulation.

The heritage of the traditional rural area represents a rich base for the dynamic development of rural tourism, because some areas have preserved their landscape and numerous traditional features, such as architecture, traditional crafts and services, a diverse and rich offer of local specialties, and especially cultural and historical diversity.The development of tourist activity in rural areas of Serbia does not have long tradition, as organised tourist turnover in these regions has started to unfold from the end of the 1970s, where in time it gained a more massive character, especially in the villages of Western Serbia. At the beginning of the new century, rural tourism has experienced stagnation due to the deep political, social and economic crisis that impacted on all segments of the society, and hence on tourism. Rural tourism has been evolving sporadically and without a plan. The long-term isolation period was not a suitable environment for improving the development of tourism and tourist offer, but already at the beginning of the 21 st century there could be recognised a slight increase in rural tourism.

One of the key characteristics of the development of rural areas in Serbia is the increasingly unfavourable age structure of the population. Negative tendencies indicate an increase in the share of elderly people, with the continuation of the process of decrease in participation nof young people, as well as the fact that every fifth inhabitant of a village in the Republic of Serbia is older than 65 years, while in the region of Southern and Eastern Serbia it is every fourth. Regarding the educational structure, persons with completed secondary school (47\%)are mostly represented, with a decrease in the share of the most educated. This decline in education of the rural population is increasingly deepening the gap between rural and urban areas, which negatively affects the competitiveness of the workforce. 
The low quality of workforce reduces the entrepreneurial potential of the workforce and causes the low economic interest of foreign investors. Such an unfavourable environment encourages further migration of educated cadres from rural to urban areas, which subsequently deepens the gap between rural and urban environment (Ministarstvo PZŽS, 2014).

\section{Potentials and limitations of rural tourism development of the Republic of Serbia}

Rural tourism has a priority in the National Strategy for Sustainable Development of Serbia (Ministarstvo PZŽS, 2014). Rural tourism is seen as a sector that has potential and this is reflected in the fact that there is a vertical institutional structure for its development. Areas with conditions suitable for the development of rural tourism referred to in the Spatial Development Strategy of the Republic of Serbia are mostly mountainous, borderlands as well as other peripheral areas whose potential for agriculture is very poor, but they have a favourable geographical location and potential for the development of rural tourism.Considering that the development of rural tourism depends largely on the geographical physiognomy of the rural area, and given the fact that more than $80 \%$ of the territory of Serbia belongs to the so-called rural area where $44 \%$ of the country's population lives, all of these are comparative advantages for the development of this type of tourism (Premović, Boljević, Arsić, 2011).

The natural and cultural diversity of the region, rich resource base of tourist attractions, preserved environment and a large number of agricultural households, confirm that the Republic of Serbia has the conditions for the development of rural and other specific forms of tourism related to rural areas. Rural tourism, significantly enriches the tourist offer and provides new quality and incentive for the development of tourism in Serbia (Đorđević-Milošević, Milovanović, 2012)

The current development of rural tourism of the Republic of Serbia can be monitored on the basis of the data published by the Statistical Office of the Republic of Serbia which relate to tourist turnover, observed in terms of realised number of tourist arrivals and overnight stays (Table 1). Unfortunately, according to the current classification of tourist sites in the Republic of Serbia, rural tourist destinations do not stand out separately.

In further classification, according to the type of tourist sites, the national statistics distinguishes the spas, mountains, other tourist destinations and other places. Accommodation capacities in rural tourism are predominantly included in the category of "other tourist destinations". Although this classification is not clearly defined and too broad, these data, however insufficiently precise, provide a certain insight in the statistics of tourist turnover in rural tourism of the Republic of Serbia. Observing the tourist turnover in the last four years, there is a continuing 
increase in the number of tourists in rural areas (Figure 1), although the data given in the text below indicate that this growth has a negligible significance in economic terms.

Table.1. Tourist traffic - realized number of tourist arrivals and nights, by types of tourist sites of rural tourism expressed in thousands and in percentages (\%)

\begin{tabular}{||c|c|c|c|c||}
\hline \hline Year & $\begin{array}{c}\text { Realized number of } \\
\text { arrivals in other tourist } \\
\text { places and other places }\end{array}$ & $(\%)$ & $\begin{array}{c}\text { Number of overnight } \\
\text { stays realized in other } \\
\text { tourist places and other } \\
\text { places }\end{array}$ & $(\%)$ \\
\hline 2014 & 582.500 & $20.91 \%$ & 1.218 .600 & $21.24 \%$ \\
\hline 2015 & 648.400 & $23.27 \%$ & 1.352 .200 & $23.56 \%$ \\
\hline 2016 & 718.100 & $25.77 \%$ & 1.486 .300 & $25.90 \%$ \\
\hline 2017 & 837.200 & $30.05 \%$ & 1.681 .300 & $29.30 \%$ \\
\hline Total & 2.786 .400 & $100 \%$ & 5.738 .400 & $100 \%$ \\
\hline
\end{tabular}

Source: Statistical Yearbook of the Republic of Serbia (2015-2018)

Based on the data of the Statistical Office of the Republic of Serbia, in the observed period from 2014 to 2017, the number of tourist arrivals and overnight stays was increasing continuously, which apparently contributed to the growing attractiveness of rural tourism destinations of the Republic of Serbia and the significance of rural tourism. However, data showing the number of beds in rural tourism of Serbia show an uneven trend, which is difficult to link with any socioeconomic factors (Statistički godišnjak Republike Srbije, 2015-2018). This clearly points to the fact that there is no well-planned strategy in the rural tourism of Serbia, nor any plans, but everything is being done in a styheous and unorganised manner, so the tourist turnover is also uneven per years. Thus, the number of accommodation facilities declined sharply in 2014 compared to the previous year, and then there was a slight increase in the number of beds in rural households in the upcoming years (Statistički godišnjak Republike Srbije, 2015-2018).

The true state of rural tourism and its role in the overall tourism industry of the Republic of Serbia is shown in the data from the year of 2017, according to which only 1,723 beds were registered in rural tourism of Serbia, or about $1.7 \%$ of the total number of beds in tourism of Serbia. Another devastating fact is that there were 16,040 overnight staysin rural tourism of Serbia in 2017, which is only $0.19 \%$ compared to the total number of overnight stays in Serbia, which clearly pointed to the insufficient utilization of already low capacities. If this is added to the information about the overnight stays of foreign visitors in rural tourism, which makes $0.02 \%$ of the total number of overnight stays of foreign visitors, it is clear that rural tourism in Serbia is still a marginal form of tourism in our national territory, although it is certain that the potential exists (Statistički godišnjak Republike Srbije, 
2015-2018). It should also be noted that there exists the great uneven territorial development of rural tourism, to the extent that the majority of rural households are located in the region of Šmadija and Western Serbia, or $74 \%$ of the total number of households in the Republic of Serbia (Novović, Gligorijević, 2018).

Figure 1. Realised number of tourist arrivals in other tourist destinations and other places of the Republic of Serbia in the period 2014-2017 (in\%)

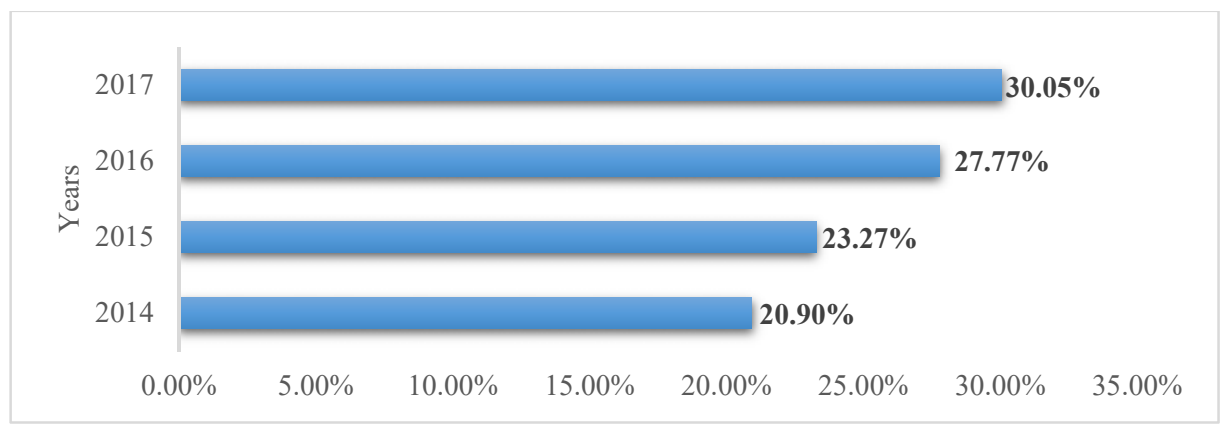

Source: Statistical Yearbook of the Republic of Serbia (2015-2018)

From all of the abovementioned, it is clear that rural tourism in Serbia is in the initial stage of development, which is caused by numerous factors (Master Plan for Sustainable Development of Rural Tourism, 2011):

1. Lack of adequate tourism, communal and transport infrastructure (poor and underdeveloped utility infrastructure, water supply, sewage network, waste management system, etc.)

2. Lack of a clear concept of the strategy for the development of rural tourism (rural tourism is not specifically included in the laws and regulations related to tourism)

3. Inadequate incentive support expressed through taxation policy and inadequate distribution of funds (access to financing in rural areas is very limited not only due to credit, but also liquidity conditions, difficult procedures for obtaining loans, unfavourable credit conditions and lack of information on this)

4. Unsatisfactory level of quality of accommodation capacities (underdevelopment and unsatisfactory level of quality of accommodation capacities, insufficient utilization of existing capacities, incomplete offer of catering services and underdevelopment of additional services, low investment capacity of households)

5. Insufficient care for the preservation of the environment and natural values (lack of government and financial support for the development of water and wastewater management in rural areas, numerous local landfills, unorganized waste collection system) 
6. Lack of interest and adequate personnel for the development of rural tourism (lack of motivation and relevant knowledge of the rural population)

7. Insufficient education of rural households inhabitants on how to accept tourists and prepare the tourist season (insufficient education of local population on rural tourism potentials)

8. Insufficient application of modern information and communication technologies (reservation process in rural tourism is not standardized and there is no clear quality guarantee)

9. Negative demographic trends and the aging process of the rural population (general shortage of workforce and deficit of specific qualifications that prevent the development of rural tourism)

Particularly strong depopulation processes in rural areas of Serbia influence the fact that the availability of labour-efficient population has become the main factor for the development of rural areas, and hence rural tourism. The Republic of Serbia has a very poor demographic structure of the rural population. This problem is particularly distinguished in mountainous areas, which have the greatest potential for the development of rural tourism. Personnel already working or preparing for work in rural tourism are forced to constantly innovate and improve their expertise, because of the increased competitiveness of knowledge and the increased competition of ideas and innovations in the tourism market, in order to discover and meet the needs of tourists during their stay in a specific tourist destination. Education of the rural population is one of the key factors for the successful development of rural tourism. Insufficient and inadequate education is the main cause of demotivation and unpreparedness of the rural population to engage in tourism business.

It should also be emphasised that the prerequistes for the development of rural tourism include not only management, collaboration and cooperation at the level of local communities, but also regional cooperation and integration into wider international programmes. The actors that play an important role in the policy and strategy of rural development and their implementation are various ministries and government bodies. At the local level, the actors that play a key role in the development of rural tourism are various associations of citizens, business associations, representatives of local communities, landowners, non-governmental organizations. Since rural tourism represents the activity of rural economy, which can lead to improvement of the living standards of the population and quality of life in the countryside, it is necessary to invest in the promotion of rural tourism in order to affirm the tourism values. Local governments can contribute to the development of rural tourism through the provision of premiums and subsidies, as well as through educating the rural population in order to improve their awareness, facilitate administrative work, approve agricultural insurance and interest-free loans. The role of the non-governmental sector is also of particular importance for the development of rural tourism. Non-profit and non-governmental institutions 
primarily play the role of research, advisory, information and communication organizations that carry out activities related to contemporary trends in tourism development, and in particular support activities for the development of rural tourism (Penić, 2015).

The strategic development of rural tourism and the tourist valorization of rural areas necessarily require a marketing strategy, especially in the creation and promotion of tourism products in rural areas. The marketing strategy must be part of the rural tourism development strategy. Certainly, in the implementation of the strategy of the rural tourism development, all modern marketing tools, such as the Internet presentations of rural tourist facilities, rural destinations, etc., should be used, printing prospectuses and brochures etc.

As a consequence of all these shortcomings, which are prevalent in the rural areas of Serbia, there is a great poverty, lack of education of the population, difficult access of rural tourist destinations, and this is all in contrast to the resource potentials of the rural areas of the Republic of Serbia.

One of the attempts to improve rural tourism in Serbia was the creation of a cluster, when the typology of rural areas was developed. The essence of cluster creation is the identification of four homogeneous groups of the region, in order to identify similarities and differences, that is, possibilities and constraints for the development of rural tourism in those regions. On that occasion, four clusters were created: Central and Western Serbia, the Region of Donje Podunavlje and Južni Banat, Eastern Serbia and Vojvodina (Master Plan for Sustainable Rural Tourism Development, 2011).

The Region of Central and Western Serbia geographically extends through rural municipalities along the rivervalleys and is located on the main roads in Serbia, radially spreading from Belgrade to Montenegro, Bosnia and Macedonia. The Region of Šmadija as a central part of Serbia is very rich in cultural and historical tourist values that are classified as cultural goods of Serbia and are under the protection of the Institute for Protection of Monuments and Culture of Serbia. The Regions of Šumadija and Pomoravlje have very favourable conditions for the development of rural tourism. The most important problems in this cluster, which hinder the development of rural tourism, are depopulation, degradation of the natural environment, infrastructure lagging etc.

The Region of Donje Podunavlje and Južni Banat represents the administrative entity of the territory of Banat. Multiculturalism is a basic characteristic that distinguishes Banat from other regions, which, from an ethnic and religious point of view, is one of the most heterogeneous regions in Europe. Rich cultural heritage, monasteries, archaeological sites, thermal and thermal-mineral water springs, hunting grounds, developed network of channels and rivers are just some of the untapped opportunities for more developed rural tourism in this region. The analysis of existing resources in the Region of Donje Podunavlje has pointed to 
insufficient accommodation capacities, unused natural and cultural-historical resources, limited road accessibility due to poor quality of roads, low level of professionalism of human resources, lack of integrated tourist information system, depopulation processes, etc. (Cvijanović et al., 2013).

Eastern Serbia (Region of Southern and Eastern Serbia) is basically a rural region oriented towards natural resources, with unused tourist potential. Eastern Serbia has exceptional potential for the development of rural tourism, but despite this, it is the cluster with the worst offer in rural tourism. In this part of Serbia, the depopulation process is the most prominent, the largest number of extinguished villages is here, and along with inadequate financial support from the state, this area has less chance of revitalizing the rural environment (Gašić, 2016).

In Vojvodina, tourism is one of the key pillars of economic development. Multiculturalism is what makes this region specific, and it preserves the heterogeneity of folk traditions and customs, folk architecture, gastronomy, etc. in the most picturesque way. Despite all the predispositions, rural tourism in Vojvodina still does not have an adequate position in the market. Like other clusters, Vojvodina has many disadvantages as well, ranging from unfavourable age structure in rural areas, through educational structure, inadequate tourist infrastructure, incomplete and poor legal regulations for categorizing facilities, poor state and local government support in financing rural tourism development etc.

\section{Conclusion}

The fact that $85 \%$ of the territory of the Republic of Serbia consists of rural areas, the large geographical diversity (hilly and mountainous areas, lowlands), wealth of natural resources, multiethnic population, rich cultural and historical heritage indicate that such rural areas could play a key role in intensifying the development of rural tourism of the Republic of Serbia. Therefore, rural tourism is imposed as an alternative possibility of economic development in a large part of the Republic of Serbia and as an element of better exploitation of the comparative advantages of rural areas.

Traditional village is characterised by a special culture of housing, dressing, eating, beliefs, opinions, behaviour. The villages represent a synonym for a healthy life and a centre for spiritual and physical recovery. The language, the folklore, songs, traditional crafts, the food and its preparation, as well as the specific gastronomy offered by a rural area, can enrich this part of the national territory in a touristic way and attract a large number of tourists. The organization of the festivals and various events, as well as the revitalization of the villages, may be one of the reasons why tourists would decide to visit the rural area. 
Serbia has good conditions for the development of rural tourism due to its geographical location, diverse landscape suitable for various types of recreation, enjoyment of food, folklore, rich cultural heritage etc. This type of tourism could significantly contribute to the protection of nature, but also to provide resources for the survival and renewal of life in the countryside. In contrast, Serbia remains at an early stage of development of rural tourism. The natural potentials of the Republic of Serbia are large, but they are not valorised and presented to the general public in a correct manner, and therefore they are not fully exploited.

The social and economic significance of the village has been neglected by deruralization and intensive urbanization. On the basis of the analysis of demographic characteristics, it is easy to notice that the demographic potential is greatly disturbed, led to the point of unsustainability and small possibilities of revitalization. Natural increase is extremely negative, the average age of the population is high, and the demotivation of the population for interest in rural tourism is also at a high level. Traffic and tourist infrastructure is not in accordance with tourist needs, there is inadequate institutional support for the development of rural tourism, lack of modern equipped accommodation capacities, unsatisfactory educational structure of human resources etc. In the positioning of a tourist product, it is necessary to cooperate with all the entities involved in the creation of a tourist product, whereby it is necessary to respect the basic rules and principles of the modern marketing-management concept, where beside the quality of the resources and conditions of business, the quality of the management structures and the quality of personnel have the key role.In order to overcome the problems that burden the further development of rural tourism, it is necessary to establish a stronger connection with municipal, regional and national tourism organizations. It is necessary that there is an adequate level of marketing, managerial and promotional activities in order to attract the target groups of tourists to the rural area and get acquainted with the quality and quantity of the rural tourism offer of the Republic of Serbia.

\section{References}

Ashley, C., Maxwell, S. (2001). Rethinking Rural Development, Development Policy Review, Vol. 19(4)

Cvijanović, D., Popović, V., Subić, J., Parušić, V. (2013).Stanje i mogućnosti razvoja održive poljoprivrede i ruralnog razvoja u Podunavlju (The state and possibilities of developing sustainable agriculture and rural development in the Danube Region), Monografija, Institut za Ekonomiku poljoprivrede, Beograd

Đorđević-Milošević, S.,Milovanović, J.(2012).Održivi turirzam u funkciji ruralnog razvoja - Mala poljoprivredna gazdinstva i ruralni turizam u Srbiji (Sustainable tourism in the function of rural development - Small farms and rural tourism in Serbia), Beograd 
Gašić, M. (2016). Turizam u funkciji razvoja ruralnih područja Južne i Istočne Srbije (Tourism in the function of developing rural areas of South and East Serbia),Doktorska disertacija, Ekonomski fakultet, Univerzitet u Nišu

Hakkarainen, M.,Seija, T.(2008).Toursm role in rural development of Finnish Lapland: interpreting national and regional strategy documents, Fennia 186, Helsinki, dostupno na https://core.ac.uk/download/pdf/52267166.pdf(pregledano 17.03.2019.)

Hall M.C., Sharples L., Cambourne B., Macionas N., (2002). Wine Tourism around the World - Developments, management and markets, Taylor \& Francis

Hall, D.R., Roberts, L., Mitchell, M. (2003). New Directions in Rural Tourism: Local Impacts, Global Trends, Hants: Ashgate Publishing

Jovičić, D.(2002).Menadžment turističkih destinacija (Management of tourist destinations), Želind, Beograd

Lane B., (1994). What is Rural Tourism?, Journal of Sustainable Tourism, Rural Tourism and Sustainable Rural Development, No. 1-2., Vol. 2., Taylor \& Francis

Master plan održivog razvoja ruralnog turizma $u$ Srbiji (Master plan for sustainable development of rural tourism in Serbia) (2011).Sustainble Tourism for Rural Development, MDGIF - MDG Achivement Fund, Beograd

Ministarstavo poljoprivrede i zaštite životne sredine (2014), Strategija poljoprivrede $i$ ruralnog razvoja za period 2014-2024.godine (Strategy for Agriculture and Rural Development for the period 2014-2024,), Službeni glasnik RS br.85/2014, Beograd

Ministarstvo životne sredine i prostornog planiranja (2009). Strategija prostornog razvoja Republike Srbije 2009-2013-2020 (Spatial Development Strategy of the Republic of Serbia 2009-2013-2020), Republička agencija za prostorno planiranje, Beograd

Novović, M., Gligorijević, Ž.(2018).Regionalna struktura ruralnog turizma Republike Srbije (Regional structure of rural tourism of the Republic of Serbia), Regionalni razvoj i demografski tokovi zemalja Jugoistočne Evrope, XXIII Medjunarodni naučni skup, Ekonomski fakultet, Univerziteta u Nišu

OECED (1994). Tourism Strategies and Rural Development, General Distribution (94)49, Paris

Penić, M. (2015).Kvalitet smeštajnih kapaciteta kao indikator razvijenosti ruralnog turizma $u$ Republici Srbiji (Quality of accommodation capacities as an indicator of the development of rural tourism in the Republic of Serbia), Doktorska disertacija, PMF - Departman za geografiju, hotelijerstvo i turizam, Univerzitet u Novom Sadu

Strategija razvoja ruralnog turizma Splitsko-dalmatinske Županije (Strategy for the development of rural tourism in the Split-Dalmatia County) (2009). Horwath Consulting Split: Turistička zajednica Splitsko-dalmatinske Županije, Hrvatska

Statistički godišnjak Republike Srbije (Statistical Yearbook of the Republic of Serbia), (2015., 2016., 2017., 2018.), Republički zavod za statistiku, Beograd

Premović, J., Boljević, A., Arsić, Lj. (2011).Resursni potencijali održivog turističkog razvoja Srbije (Resource potentials of sustainable tourism development of Serbia), VI Medjunarodni naučni skup „Mediteranski dani”, Turizam i ruralni razvoj savremene tendencije, problemi i mogućnosti razvoja, Tematski zbornik, Trebinje 


\section{PERSPEKTIVE RAZVOJA RURALNOG TURIZMA REPUBLIKE SRBIJE}

Rezime: Ruralni turizam predstavlja turizam seoskih domaćinstava, ali i odmor i boravak u seoskoj sredini, manifestacije, festivale, rekreaciju, proizvodnju i prodaju ručnih radova, zanantskih i poljoprivrednih proizvoda. Ruralni turizam je naročito prikladan za revitalizaciju degradiranih ruralnih oblasti obezbeđujući njihovu održivost $u$ budućnosti, kroz stvaranje novih radnih mesta, povećanje raznolikosti zanimanja, seoskih zanata, kao i očuvanje pejzaža i prirode. Razvoj ruralnog turizma Republike Srbije trebalo bi da igra značajnu ulogu u ruralnom razvoju države i privrednom razvoju uopšte. Zahvaljujući raznovrsnom reljefu i očuvanoj prirodi, Srbija raspolaže značajnim resursima u ruralnom turizmu, ali nije zanemarljiv ni broj negativnih faktora, koji onemogućavaju intenzivniji rast ove privredne grane. Jedan od najznačajnijih, ali ne i nerešivih problema, jeste odumiranje seoskih naselja Srbije.

Ključne reči: ruralni turizam, selo, održivi turizam, ruralni prostor

\section{Authors' biographies}

Dejan Ž. Đorđević is Associate Professor at Faculty of Economics, University of Niš., where he teaches undergraduate courses in Economic Geography, Tourism Geography and Regional Geography. He has authored numerous scientific and research articles in various kinds of publication and also published scientific and professional papers in domestic and international journals in the fields of Economic and Tourism Geography.

Vukašin Šušić is a Full Professor at the Faculty of Economics in Niš. He teaches at the basic academic studies, graduate academic master studies and $\mathrm{PhD}$ studies, the subjects from scientific area of economic geography. From 2003 to 2014 he was a honorary associate at the Department of Geography of the Faculty of Natural Science and Matematics in Niš for industrial and agrarian geography subjects. He published over 70 works and participated in many scentific meetings. $\mathrm{He}$ is the author of the Tourism Geography coursebook and a coauthor of the Economic Geography - Serbian and Montenegro and Geography of the World course books. He is a member of the Serbian Geographical Society.

Ivana Janjić is a PhD student, module Business Managment at the Faculty of Economics in Niš. She also works as an research trainee at Innovation Center at the University of Niš. She is a researcher at the project No.179066 supported by Ministry Education, Science and Technological Development of the Republic of Serbia. She has published numerous papers in scientific and professional journals and she has participated at conferences in the country and abroad. 